\title{
Effects of Protozoa and Glass Beads on Bacterial Biomass and Metabolism in a Food Chain System of Glucose- Pseudomonas sp. strain DP-4-Tetrahymena thermophila
}

\author{
MitsunOri TARAO ${ }^{*}$, YOSHIRO YAMASHITA ${ }^{1}$, AKIRA SATO $^{1}$ and MASAYUKi SETO ${ }^{1}$ \\ ${ }^{1}$ Laboratory of Environmental Microbiology, Department of Environmental and Natural Resource Science, \\ Tokyo University of Agriculture and Technology, Fuchu, Tokyo 183-8509, Japan
}

(Received March 4, 2002-Accepted June 23, 2002)

The effect of the protozoa Tetrahymena thermophila or glass beads on the biomass of the bacterium Pseudomonas sp. strain DP-4 and metabolism of glucose in a steady state was studied in a food chain system of glucose-Pseudomonas sp. strain DP-4-T. thermophila. Glucose was added to $1.5 \mathrm{ml}$ cultures in $50 \mathrm{ml}$ vials at a rate of $50 \mu \mathrm{g} \mathrm{C/vial/day.} \mathrm{In} \mathrm{the} 1.5 \mathrm{ml}$ cultures without glass beads, the bacterial biomass was ca. 450 and $26 \mu \mathrm{g}$ $\mathrm{C} /$ vial when the protozoa was absent and present, respectively. The bacterial biomass with glass beads was ca. 650 and $34 \mu \mathrm{g} \mathrm{C} /$ vial when the protozoa was absent and present, respectively. Protozoan biomass was 7 and 20 $\mu \mathrm{g} \mathrm{C/vial} \mathrm{without} \mathrm{or} \mathrm{with} \mathrm{glass} \mathrm{beads,} \mathrm{respectively.} \mathrm{Irrespective} \mathrm{of} \mathrm{presence} \mathrm{of} \mathrm{the} \mathrm{protozoa} \mathrm{or} \mathrm{glass} \mathrm{beads,} \mathrm{the}$ rate of consumption of glucose per vial $(50 \mu \mathrm{g} \mathrm{C/vial/day)} \mathrm{was} \mathrm{considered} \mathrm{to} \mathrm{be} \mathrm{almost} \mathrm{the} \mathrm{same} \mathrm{as} \mathrm{the} \mathrm{rate} \mathrm{of}$ $\mathrm{CO}_{2}$ evolution per vial (45-47 $\mu \mathrm{g} \mathrm{C} / \mathrm{vial} /$ day). The diameter of the glass beads (50, 70 or $\left.100 \mu \mathrm{m}\right)$ had no effect on the bacterial biomass in the absence of the protozoa. While, in the presence of the protozoa, the bacterial biomass was greatest when the diameter of glass beads was just $50 \mu \mathrm{m}$. These results suggested that the rate of glucose consumption per unit bacterial biomass of $0.11 \mu \mathrm{g}$ glucose- $\mathrm{C} / \mu \mathrm{g}$ biomass-C/day was increased to $1.9 \mu \mathrm{g}$ glucose-C/ $\mu \mathrm{g}$ biomass-C/day by protozoan predation, while the value was decreased to $0.077 \mu \mathrm{g}$ glucose-C/ $\mu \mathrm{g}$ biomass-C/day by glass beads. The significance of protozoan predation and particles for bacterial biomass and metabolic activity was discussed.

Key words: carbon balance, biomass, respiration rate, food chain, particulate matrix

Bacteria comprise $18-50 \%$ of the total microbial biomass in arable soil ${ }^{16)}$, and are considered to play a significant role in the carbon cycle in soil through the detritus food chain. However the mechanisms that regulate bacterial biomass, substrate consumption, and $\mathrm{CO}_{2}$ evolution in soil, are poorly understood.

A number of studies reported that, in an aquatic environment or liquid medium, protozoan predation decreased bacterial biomass ${ }^{4,19,21,23)}$ or enhanced the rate of bacterial turnover ${ }^{1,11,22)}$. While, in soils, studies of the effect of protozoan predation on bacterial biomass, substrate consumption, and $\mathrm{CO}_{2}$ evolution are limited ${ }^{10)}$. Particles, a distinctive fea-

\footnotetext{
* Corresponding author; E-mail: tarao@cc.tuat.ac.jp, Tel: +81-42367-5852, Fax: +81-42-367-5731
}

ture of soil environment, are another factor influencing bacterial metabolic activity ${ }^{2,3,6,9,14)}$, but their effect on bacterial biomass, substrate consumption, and $\mathrm{CO}_{2}$ evolution remains unknown. There is evidence to suggest that particles affect the protozoan predation of bacteria by providing small porous habitats that protect bacteria ${ }^{5,24)}$ or due to the development of biofilms on their surface ${ }^{4}$. However, the combined effect of protozoan predation and particles on bacterial biomass, substrate consumption, and $\mathrm{CO}_{2}$ evolution is limited.

In order to elucidate the limiting factor for bacterial biomass, substrate consumption, or $\mathrm{CO}_{2}$ evolution in soil, we focused on the effect of protozoan predation, particles, and a combination of the two. We compared the microbial biomass, the rate of substrate consumption, and the rate of $\mathrm{CO}_{2}$ evolution in a food chain system consisting of a bacterial 
isolate and a protozoan isolate in culture without or with glass beads where glucose was supplied continuously.

\section{Materials and Methods}

\section{Bacterial and protozoan strains}

Pseudomonas sp. strain DP-420) was used as a model bacterium. It was precultured in an inorganic salt solution containing $1.6 \mathrm{mg} \mathrm{C} / \mathrm{ml}$ of glucose for four days with shaking at $25^{\circ} \mathrm{C}$ in the dark. Tetrahymena thermophila inbred strain B provided by Dr. T. Sugai of Ibaraki University was used as a model protozoa. It was precultured in an autoclaved bacterial suspension $(150 \mu \mathrm{g} \mathrm{C} / \mathrm{ml}$ of biomass of strain DP-4) for four days with gentle shaking at $25^{\circ} \mathrm{C}$ in the dark.

\section{Culture system}

Pure cultures of the bacterium and mixed cultures of the bacterium with the protozoa were grown in the presence and absence of glass beads. Thus, four culture systems were used. One milliliter of the bacterial suspension and $0.25 \mathrm{ml}$ of autoclaved inorganic salt medium containing $100 \mu \mathrm{g} \mathrm{C}$ of glucose were added to a sterilized $50 \mathrm{ml} \mathrm{screw-cap} \mathrm{vial.} \mathrm{For}$ the cultures with glass beads, a vial containing $5 \mathrm{~g}$ of glass beads (diameter, 50,70 , or $100 \mu \mathrm{m}$ ) was used. Unless otherwise indicated, $70 \mu \mathrm{m}$ glass beads were used. Then, $0.25 \mathrm{ml}$ of the protozoan suspension was added when the bacterium was to be cultured in the presence of protozoa. When the bacterium was cultured in the absence of protozoa, $0.25 \mathrm{ml}$ of an autoclaved protozoan suspension was added. All the cultures were incubated at $25^{\circ} \mathrm{C}$ in the dark in a desiccator in which the humidity was kept at $20 \%$. An amount of inorganic salt solution containing $100 \mu \mathrm{g} \mathrm{C}$ of glucose equal to that lost by evaporation during the incubation was added every two days. Therefore, glucose was estimated to be added at $50 \mu \mathrm{g} \mathrm{C} / \mathrm{vial} / \mathrm{day}$. Unless otherwise indicated, the size of the bacterium and protozoa was 470 and $10 \mu \mathrm{g}$ biomass-C/ vial, respectively.

\section{Composition of inorganic salt solution}

The inorganic salt solution contained $6.9 \mathrm{mM} \mathrm{Na}_{2} \mathrm{HPO}_{4}$, $2.97 \mathrm{mM} \mathrm{KH}_{2} \mathrm{PO}_{4}, 3.2 \mathrm{mM} \mathrm{NH}_{4} \mathrm{NO}_{3}, 33 \mu \mathrm{M} \mathrm{MgSO}, 33$ $\mu \mathrm{M} \mathrm{CaCl}_{2}, 9.9 \mu \mathrm{M} \mathrm{Na}_{2} \mathrm{SiO}_{3}, 3.3 \mu \mathrm{M} \mathrm{MnCl}_{2}, 3.3 \mu \mathrm{M} \mathrm{H}_{3} \mathrm{BO}_{3}$, $3.3 \mu \mathrm{M} \mathrm{Na}_{2} \mathrm{MoO}_{4}, 0.66 \mu \mathrm{M} \mathrm{FeCl}_{3}, 16.5 \mathrm{nM} \mathrm{CuSO}_{4}, 16.5 \mathrm{nM}$ $\mathrm{ZnSO}_{4}$, and $16.5 \mathrm{nM} \mathrm{CoSO}_{4}$ in deionized water. The $\mathrm{pH}$ was adjusted to 7.0 .

\section{Measurement of microbial biomass carbon}

The bacterial biomass in terms of carbon amount was calculated from the difference between the total amount of or- ganic carbon (TOC) and the amount dissolved (DOC) and the protozoan biomass carbon. The sample for TOC measurement was obtained by disrupting samples in the vial with $10 \mathrm{ml}$ of deionized water and $1 \mathrm{ml}$ of orthophosphoric acid. The sample for DOC measurement was obtained as follows: the culture in the vial with $10 \mathrm{ml}$ of deionized water was passed through a $0.45 \mu \mathrm{m}$-pore-sized durapore membrane filter (HVLP, Millipore Corp.), and the filtrate was added to $1 \mathrm{ml}$ of orthophosphoric acid. The amount of organic carbon in samples was measured using a nondispersive infrared gas analyzer with $1.0 \mathrm{~g}$ of potassium peroxodisulfate and a modified oxidation vessel ${ }^{18}$. Glass beads did not affect the measurement of organic carbon.

The protozoan biomass in terms of carbon was measured as follows: $B c=N \times V \times G s \times D w \times C c$, where $B c$ is protozoan biomass carbon, $N$ is mean cell number $(\mathrm{n}=4), V$ is mean cell volume $\left(3370 \mu \mathrm{m}^{3}, \mathrm{n}=82\right), G s$ is cell specific gravity $\left.\left(1.1 \mathrm{~g} / \mathrm{cm}^{3}\right)^{8}\right), D w$ is ratio of dry weight $(0.2)$, and $C c$ is carbon content per dry weight (0.5).

Estimation of rates of glucose consumption and $\mathrm{CO}_{2}$ evolution in the steady state

The rate of glucose consumption per unit bacterial biomass was the rate of glucose consumption per vial divided by bacterial biomass. The rate of glucose consumption per vial was the rate of glucose addition ( $50 \mu \mathrm{g} \mathrm{C} / \mathrm{vial} /$ day), because no remaining glucose in the culture was detected. Bacterial biomass was calculated from biovolume, cell specific gravity $\left(1.1 \mathrm{~g} / \mathrm{cm}^{3}\right)$, ratio of dry weight $(0.25)$, and carbon content per dry weight $(0.45)$. Bacterial biovolume was estimated by a direct count method using phenolic anilin blue $(\mathrm{PAB})^{7,16)}$.

The rate of $\mathrm{CO}_{2}$ evolution per vial was the difference between the rate of glucose consumption per vial and the rate of DOC excretion and/or the rate of excretion of particulate waste products by the protozoa. The DOC excretion rate was amount of DOC in the culture divided by the incubation period. The rate of excretion of particulate waste products by the protozoa was calculated as the amount of particulate waste products in the culture divided by the incubation period.

\section{Statistical analyses}

Analysis of variance (ANOVA) was used to test the effect of the pore size of glass beads on the mean size of the protozoa in the culture with three different diameters of glass beads at 40-day-incubation. Scheffe's multiple range test was then used to find which cultures were significantly different. All analyses were performed using SPSS $^{\circledR}$ Base 
System Release 6.13J for Windows (SPSS Japan Inc.).

\section{Results}

In the culture without glass beads, when the protozoa was absent, the bacterial biomass was almost constant, 420$470 \mu \mathrm{g} \mathrm{C} / \mathrm{vial}$, during the 50-day-incubation period (Fig. 1 (a)). On the other hand, when present, the bacterial biomass decreased, reaching a steady state (110-180 $\mu \mathrm{g}$ C/vial) after 26 days incubation. After a transient increase, the protozoan biomass reached a steady state (5-12 $\mu \mathrm{g}$ C/vial) after 26 days incubation (Fig. 1 (b)).

In the culture with glass beads (diameter, $70 \mu \mathrm{m}$ ), when the protozoa was absent, the bacterial biomass increased gradually during the 40-day-incubation period, then reached a steady state (620-630 $\mu \mathrm{g} \mathrm{C/vial)} \mathrm{(Fig.} 2$ (a)). On the other hand, when present, the bacterial biomass decreased and reached a steady state (84-170 $\mu \mathrm{g}$ C/vial) after 26 days incubation (Fig. 2 (a)). After a transient increase, the protozoan biomass reached a steady state (14-16 $\mu \mathrm{g} \mathrm{C/vial)} \mathrm{after}$ 26 days incubation (Fig. 2 (b)).

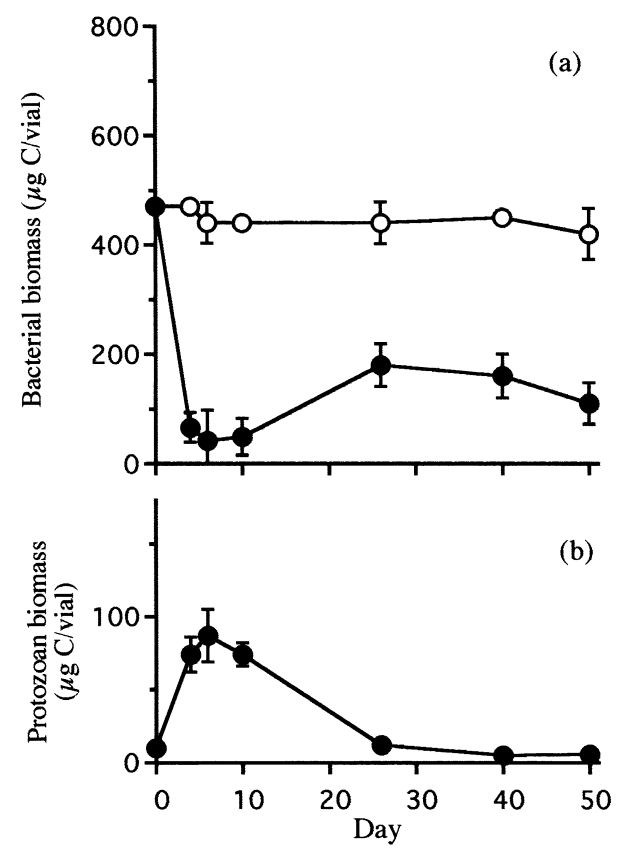

Fig. 1. Change in bacterial biomass (a) when the protozoa was absent (open circle) or present (close circle), and change in protozoan biomass (b) in $1.5 \mathrm{ml}$ cultures in $50 \mathrm{ml}$ vials without glass beads. Bacterial biomass included particulate waste products excreted by protozoa when present. Glucose was added at a rate of $50 \mu \mathrm{g} \mathrm{C} / \mathrm{vial} /$ day. Each value of bacterial biomass and protozoan biomass is the mean of three and four measurements, respectively. Bars indicate the range of minimum and maximum values.
Table 1. Amount ( $\mu \mathrm{g} \mathrm{C/vial)} \mathrm{of} \mathrm{bacterial} \mathrm{biomass}{ }^{\mathrm{a}}$ at 40 days incubation with different inoculations of bacterial biomass in culture with glass beads. ${ }^{\mathrm{b}}$

\begin{tabular}{cccc}
\hline \multirow{2}{*}{ Protozoa } & \multicolumn{3}{c}{ Initial bacterial biomass $(\mu \mathrm{g} \mathrm{C} /$ vial $)$} \\
\cline { 2 - 4 } & 160 & 470 & 710 \\
\hline Absent & $590(550-630)$ & $630(590-670)$ & $660(610-710)$ \\
Present & $200(190-230)$ & $100(70-130)$ & $150(110-190)$ \\
\hline
\end{tabular}

${ }^{\mathrm{a}}$ Bacterial biomass included particulate waste products excreted by protozoa if present.

${ }^{b}$ Each value is the mean of three measurements. Minimum and maximum values are shown in parentheses. The diameter of the glass beads was $70 \mu \mathrm{m}$.

The effect of inoculum size on the bacterial biomass at 40 days incubation in the culture with glass beads was evaluated (Table 1). Irrespective of size, the bacterial biomass was almost the same, 590-660 and 100-200 $\mu \mathrm{g}$ C/vial, when the protozoa was absent and present, respectively.

Direct counting at 40 days incubation revealed that when

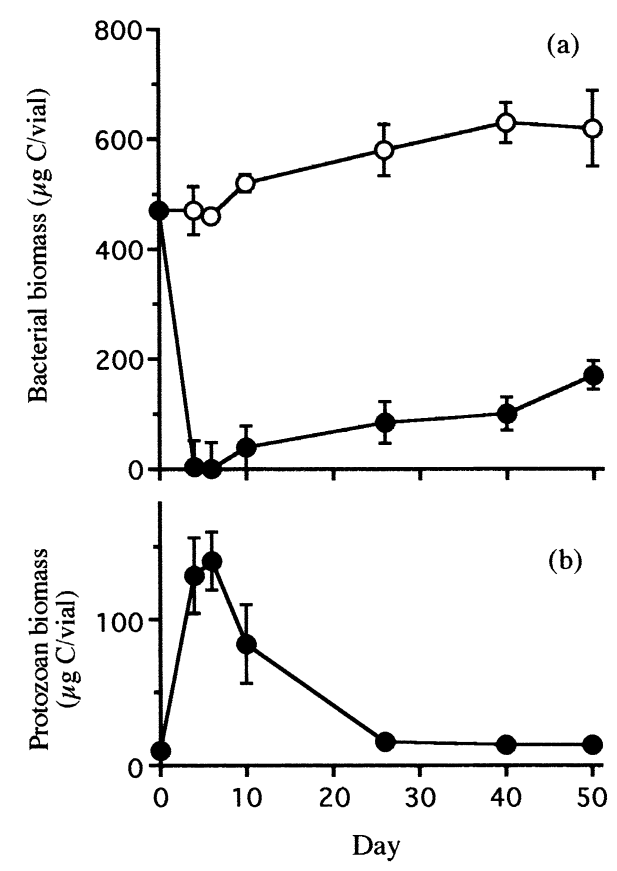

Fig. 2. Change in bacterial biomass (a) when the protozoa was absent (open circle) or present (close circle), and change in protozoan biomass (b) in $1.5 \mathrm{ml}$ cultures in $50 \mathrm{ml}$ vials with glass beads. Bacterial biomass included particulate waste products excreted by protozoa when present. Glucose was added at a rate of $50 \mu \mathrm{g} \mathrm{C} / \mathrm{vial} / \mathrm{day}$. The diameter of the glass beads was $70 \mu \mathrm{m}$. Each value of bacterial biomass and protozoan biomass is the mean of three and four measurements, respectively. Bars indicate the range of minimum and maximum values. 
Table 2. Amount ( $\mu \mathrm{g} \mathrm{C/vial)} \mathrm{of} \mathrm{bacterial} \mathrm{biomass} \mathrm{and} \mathrm{particulate}$ waste products excreted by protozoa at 40 days incubation when protozoa was present in culture without or with glass beads. ${ }^{\mathrm{a}}$

\begin{tabular}{lcc}
\hline Glass beads & Bacterial biomass & $\begin{array}{c}\text { Amount of particulate waste } \\
\text { products }\end{array}$ \\
\hline Without & 26 & 46 \\
With & 34 & 35 \\
\hline
\end{tabular}

a The diameter of the glass beads was $70 \mu \mathrm{m}$.

the protozoa was present, the bacterial biomass consisted of not only bacterial cells but also particulate waste products excreted by the protozoa. In the culture without glass beads, the bacterial biomass and the amount of particulate waste products was 26 and $46 \mu \mathrm{g}$ C/vial, respectively (Table 2). In the culture with glass beads, this was 34 and $35 \mu \mathrm{g} \mathrm{C/}$ $\mathrm{ml}$, respectively. When the protozoa was absent, the bacterial biomass in the culture without and with glass beads was almost the same with POC of 450 and $650 \mu \mathrm{g} \mathrm{C} / \mathrm{vial}$, respectively (data not shown).

The carbon balance in each culture at 40 days incubation was determined (Fig. 3). When the protozoa was absent, the bacterial biomass in the culture without and with glass beads was 17 and 19 times higher than when the protozoa was present. The rates of glucose consumption and $\mathrm{CO}_{2}$ evolution were similar among the cultures. When the protozoa was absent, the rate of glucose consumption per unit bacterial biomass was 0.11 and $0.077 \mu \mathrm{g}$ glucose-C/ $\mu \mathrm{g}$ biomass-C/day in the culture without and with glass beads, respectively. While, when the protozoa was present, the corresponding values were 1.9 and $1.5 \mu \mathrm{g}$ glucose-C/ $\mu \mathrm{g}$ biomass-C/day, respectively.

The effect that the size of the glass beads had on the bacterial biomass at 40 days incubatoin was evaluated (Table 3 ). When the protozoa was absent, the bacterial biomass in the culture without glass beads was the smallest of all. Irrespective of the diameter of the beads, the bacterial biomass was almost the same, 630-670 $\mu \mathrm{g} \mathrm{C/vial.} \mathrm{When} \mathrm{the} \mathrm{proto-}$ zoa was present, irrespective of the presence or diameter

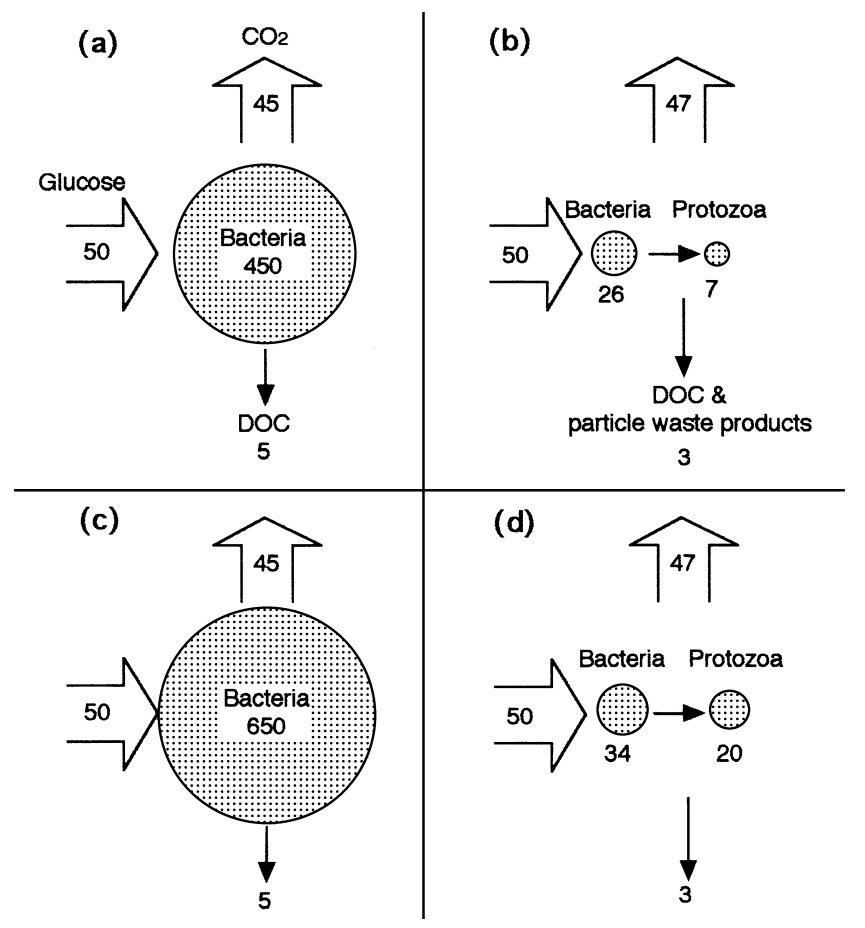

Fig. 3. Carbon balance showing successive intake and transfer of carbon at 40 days incubation when the protozoa was absent $(a, c)$ or present $(b, d)$ in the culture without $(a, b)$ or with $(c, d)$ glass beads. The area of a circle shows biomass ( $\mu \mathrm{g} \mathrm{C} / \mathrm{vial})$ respectively, and the arrow shows the rate of intake and transfer ( $\mu \mathrm{g} \mathrm{C} / \mathrm{vial} /$ day). The diameter of the glass beads was $70 \mu \mathrm{m}$.

(except $50 \mu \mathrm{m}$ ) of glass beads, the bacterial biomass was almost the same at 100-160 $\mu \mathrm{g} \mathrm{C} / \mathrm{vial}$, while it was the greatest, at $300 \mu \mathrm{g} \mathrm{C} / \mathrm{vial}$, when the diameter of the beads was $50 \mu \mathrm{m}$.

Assuming that the glass beads in the vial were as cubic closest packed structure, the pore size of glass beads was calculated (Table 4). Data from ANOVA performed on the long length of the protozoa showed no significant difference among cultures, while a significant difference in short length was observed $(P<0.01)$. When the smaller glass beads were used, the short length of the protozoa was

Table 3. Amount ( $\mu \mathrm{g} \mathrm{C} / \mathrm{vial})$ of bacterial biomass ${ }^{\mathrm{a}}$ at 40 days incubation when the protozoa was absent or present in the culture without or with glass beads of three different diameters. ${ }^{b}$

\begin{tabular}{ccccc}
\hline \multirow{2}{*}{ Protozoa } & Without glass beads & \multicolumn{3}{c}{ Diameter of glass beads added } \\
\cline { 3 - 4 } & & $50 \mu \mathrm{m}$ & $70 \mu \mathrm{m}$ & $100 \mu \mathrm{m}$ \\
\hline Absent & $450(440-460)$ & $670(640-700)$ & $630(590-670)$ & $640(580-700)$ \\
Present & $160(120-200)$ & $300(280-330)$ & $100(70-130)$ & $140(100-180)$
\end{tabular}

${ }^{a}$ Bacterial biomass included particulate waste products excreted by protozoa when present.

${ }^{\mathrm{b}}$ Each value is the mean of three measurements. Minimum and maximum values are shown in parentheses. 
Table 4. Relationship between pore size of glass beads and mean size of protozoa at 40 days incubation.

\begin{tabular}{|c|c|c|c|c|c|}
\hline \multirow{2}{*}{ Diameter of glass beads $(\mu \mathrm{m})$} & \multirow{2}{*}{ Pore size of glass beads ${ }^{1)}(\mu \mathrm{m})$} & \multicolumn{3}{|c|}{ Mean size $(\mu \mathrm{m} \pm \mathrm{SE})$ of protozoa } & \multirow{2}{*}{$\begin{array}{l}\text { Density of protozoa } \\
\quad\left(\times 10^{4} \mathrm{cell} / \mathrm{vial}\right)\end{array}$} \\
\hline & & Long length & Short length & $\mathrm{n}$ & \\
\hline 50 & 7.7 & $23 \pm 0.9$ & $12 \pm 0.6 \mathrm{a}^{3)}$ & 15 & $1.6 \pm 0.18$ \\
\hline 70 & 11 & $26 \pm 0.7$ & $14 \pm 0.4 \mathrm{ab}^{3)}$ & 25 & $3.3 \pm 0.37$ \\
\hline 100 & 15 & $26 \pm 0.9$ & $16 \pm 0.5 \mathrm{~b}^{3)}$ & 22 & $3.0 \pm 0.26$ \\
\hline Without glass beads & - & $27 \pm 1.1$ & $15 \pm 0.5 b^{3)}$ & 20 & $1.2 \pm 0.42$ \\
\hline
\end{tabular}

1) Diameter of maximum inscribed sphere between glass beads in cubic closest packed structure.

2) The mean of four measurements $( \pm \mathrm{SE})$.

3) Values followed by different letters are significantly different among the cultures (Scheffe's multiple range test; $P<0.01$ ).

smaller. The number of protozoa was smallest when the glass beads were $50 \mu \mathrm{m}$ in diameter. In the culture without glass beads, the size of the protozoa was almost the same as in the culture with glass beads except for the $50 \mu \mathrm{m}$ glass beads. The number of protozoan was smaller in the culture without than with glass beads.

\section{Discussion}

Our study revealed that, (i) protozoan predation decreased the bacterial biomass, (ii) the presence of glass beads increased the bacterial biomass, and (iii) neither protozoan predation nor glass beads affected the rate of glucose consumption per vial or $\mathrm{CO}_{2}$ evolution per vial. These results indicated that protozoan predation increased glucose consumption per unit bacterial biomass, while the presence of glass beads decreased it.

The rate of $\mathrm{CO}_{2}$ evolution per unit bacterial biomass was estimated only when the protozoa was absent, and was 0.10 and $0.069 \mu \mathrm{g} \mathrm{CO}_{2}-\mathrm{C} / \mu \mathrm{g}$ biomass-C/day in the culture without and with glass beads, respectively. These values are similar to the rate of $\mathrm{CO}_{2}$ evolution per unit microbial biomass in arable soil reported to be $0.02-0.06^{13)}, 0.075^{15)}$, or $0.042^{17)} \mu \mathrm{g} \mathrm{CO}_{2}-\mathrm{C} / \mu \mathrm{g}$ biomass-C/day. The rate of $\mathrm{CO}_{2}$ evolution per unit bacterial biomass when the protozoa was present was not estimated directly. Assuming that the yield coefficient of the bacterium at the expense of glucose is 0.5 and ignoring the rate of DOC excretion, the rate at which $\mathrm{CO}_{2}$ evolves is estimated at $25 \mu \mathrm{g} \mathrm{CO}-\mathrm{C} /$ day. Then, the estimated rate per unit bacterial biomass is 0.96 and $0.73 \mu \mathrm{g}$ $\mathrm{CO}_{2}-\mathrm{C} / \mu \mathrm{g}$ biomass-C/day in the culture without and with glass beads, respectively. These values are 10 times higher than when the protozoa was absent.

From the increase in the rates of glucose consumption and $\mathrm{CO}_{2}$ evolution per unit bacterial biomass when the protozoa was present, it is considered that the specific metabolic activity of the bacteria was enhanced by protozoan predation as other studies ${ }^{1,11,12)}$ have reported. This enhancement was apparently not caused by the decrease in bacterial biomass due to protozoan predation. Assuming that the yield coefficient of the bacterium at the expense of glucose is 0.5 , bacterial biomass is produced at a rate of $25 \mu \mathrm{g}$ biomass-C/day. If the value was summed with the amount of bacterial biomass when the protozoa was present, the theoretical amount of bacterial biomass assuming the absence of the protozoa was obtained, i.e., 51 and $59 \mu \mathrm{g} \mathrm{C} / v i a l$ in the culture without and with glass beads, respectively. Because these values are much lower than when the protozoa was absent, the enhancement of the rate of glucose consumption per unit bacterial biomass was not due to a decrease of bacterial biomass.

The larger amounts of bacterial biomass in the culture with glass beads suggested that the maintenance requirement per unit bacterial biomass was smaller than in the culture without glass beads. In the steady state when the protozoa was absent, the rate of glucose consumption per unit bacterial biomass of $50 \mu \mathrm{g}$ glucose- $\mathrm{C} / \mu \mathrm{g}$ biomass-C/day was considered to be equal to the maintenance requirement per unit bacterial biomass. While, in the steady state when the protozoa was present, the rate of bacterial consumption by the protozoa was equal to the rate of bacterial production, and the value was considered to be equal to the maintenance requirement of the protozoa. The larger amounts of protozoan biomass in the culture with glass beads suggested that the maintenance requirement per unit protozoan biomass was smaller than in the culture without glass beads, or the yield coefficient of the bacterium at the expense of glucose was larger.

When the protozoa was present, the bacterial biomass was highest in the culture in which the diameter of glass beads was $50 \mu \mathrm{m}$ (Table 3). In the culture with $50 \mu \mathrm{m}$ beads, the pore size was calculated at $7.7 \mu \mathrm{m}$, which was 
much smaller than the size of the protozoa (Table 4). We considered that the small size of the liquid phase impeded the motility of the protozoa, and so some bacterial cells avoided protozoan predation. In a soil environment, the location of bacteria in small pores $(<6 \mu \mathrm{m})$ provides significant protection from protozoan predation ${ }^{24)}$. If we had used smaller $(<50 \mu \mathrm{m})$ glass beads, the bacterial biomass might have become much larger even when the protozoa was present because of significant protection from predation, and the rate of glucose consumption per unit bacterial biomass would be expected to be similar to that when the protozoa was absent.

Although we used a simple culture system, we obtained basic information on the effects of protozoan predation and particles on the carbon balance especially in soil ecosystems in which protozoa or particles are major components. Our next focus in this field is to evaluate the effects of a more complex culture system, which contains bacterial species or fungi, on the bacterial or microbial biomass, bacterial activity, or carbon balance. Studies to evaluate the effects of particles are also needed.

\section{References}

1) Biagini, G.A., B.J. Finlay and D. Lloyd. 1998. Protozoan stimulation of anaerobic microbial activity: enhancement of the rate of terminal decomposition of organic matter. FEMS Microbiol. Ecol. 27: 1-8.

2) Bonin, P., J.-F. Rontani and L. Bordenave. 2001. Metabolic differences between attached and free-living marine bacteria: inadequacy of liquid cultures for describing in situ bacterial activity. FEMS Microbiol. Lett. 194: 111-119.

3) Bright, J.J. and M. Fletcher. 1983. Amino acid assimilation and electron transport system activity in attached and free-living marine bacteria. Appl. Environ. Microbiol. 45: 818-825.

4) Hahn, M.W. and M.G. Höfle. 1998. Grazing pressure by a bacteriovorous flagellate reverses the relative abundance of Comamonas acidovorans PX54 and Vibrio strain CB5 in chemostat cocultures. Appl. Environ. Microbiol. 64: 1910-1918.

5) Hattori, T. 1992. Distribution and movement of protozoa within and among soil aggregates. Bull. Jpn. Soc. Microb. Ecol. 7: 6974.

6) Jeffrey, W.H. and J.H. Paul. 1986. Activity measurements of planktonic microbial and microfouling communities in a eutrophic estuary. Appl. Environ. Microbiol. 51: 157-162.

7) Jenkinson, D.S., D.S. Powlson and R.W.M. Wedderburn. 1976. The effects of biocidal treatments on metabolism in soil. III. The relation between soil biovolume, measured by optical microscopy, and the flush of decomposition caused by fumigation. Soil Biol. Biochem. 8: 189-202.

8) Jenkinson, D.S. and J.N. Ladd. 1981. Microbial biomass in soil: measurement and turnover, p. 415-471. In E.A. Paul and J.N. Ladd (ed.), Soil Biochemistry Vol. 5. Marcel Dekker, New York.
9) Kirchman, D. and R. Mitchell. 1982. Contribution of particlebound bacteria to total microheterotrophic activity in five ponds and two marshes. Appl. Environ. Microbiol. 43: 200-209.

10) Kuikman, P.J., J.D. van Elsas, A.G. Jansen, S.L.G.E. Burgers and J.A. van Veen. 1990. Population dynamics and activity of bacteria and protozoa in relation to their spatial distribution in soil. Soil Biol. Biochem. 22: 1063-1073.

11) Mattison, R.G. and S. Harayama. 2001. The predatory soil flagellate Heteromita globosa stimulates toluene biodegradation by a Pseudomonas sp. FEMS Microbiol. Lett. 194: 39-45.

12) Ratsak, C.H., K.A. Maarsen and S.A.L.M. Kooijman. 1996. Effects of protozoa on carbon mineralization in activated sludge. Water Res. 30: 1-12.

13) Sakamoto, K. and Y. Oba. 1994. Effect of fungal to bacterial biomass ratio on the relationship between $\mathrm{CO}_{2}$ evolution and total soil microbial biomass. Biol. Fertil. Soils 17: 39-44.

14) Samuelsson, M.-O. and D.L. Kirchman. 1990. Degradation of adsorbed protein by attached bacteria in relationship to surface hydrophobicity. Appl. Environ. Microbiol. 56: 3643-3648.

15) Sato, A. and M. Seto. 2000. Rate of microbial respiration per unit biomass and carbon balance in a volcanic soil-Comparison among three land uses-. Soil Microorganisms 54: 13-21 (In Japanese with English summary).

16) Sato, A. and M. Seto. 2000. Fungal or bacterial biomass in a volcanic soil with various land uses and soil treatments. Soil Microorganisms 54: 23-30 (In Japanese with English summary).

17) Sato, A. and M. Seto. 1999. Relationship between rate of carbon dioxide evolution, microbial biomass carbon, and amount of dissolved organic carbon as affected by temperature and water content of a forest and an arable soil. Commun. Soil Sci. Plant. Anal. 30: 2593-2605.

18) Seto, M. and I. Tange. 1980. Rapid and sensitive method for the determination of total organic carbon in soil by potassium persulfate-nondispersive infrared gas analyzer. J. Sci. Soil Manure. 51: 27-30 (In Japanese).

19) Seto, M., F. Tsurui and T. Miyata. 1988. Elimination of bacterium by ciliate: effect of auxiliary organic substrate on the monoxenic culture of Pseudomonas sp.-Tetrahymena thermophila. Man \& Environ. 14: 23-30 (In Japanese with English summary).

20) Seto, M. and F. Tsurui. 1989. Survival of 2,4-dichlorophenol (DCP)-degraders and their expression of DCP-degrading activity in water samples from aquatic environment. Man \& Environ. 15: 18-24 (In Japanese with English summary).

21) Sherr, B.F., E.B. Sherr and J. McDaniel. 1992. Effect of protistan grazing on the frequency of dividing cells in bacterioplankton assemblages. Appl. Environ. Microbiol. 58: 2381-2385.

22) Šimek, K., J. Vrba, J. Pernthaler, T. Posch, P. Hartman, J. Nedoma and R. Psenner. 1997. Morphological and compositional shifts in an experimental bacterial community influenced by protists with contrasting feeding models. Appl. Environ. Microbiol. 63: 587-595.

23) Suzuki, K. and M. Seto. 1993. An ecological study on the decrease of bacterial density by protozoan grazing. Man \& Environ. 19: 23-29 (In Japanese with English summary).

24) Wright, D.A., K. Killham, L.A. Glover and J.I. Prosser. 1995. Role of pore size location in determining bacterial activity during predation by protozoa in soil. Appl. Environ. Microbiol. 61: $3537-3543$. 